Reprod. Nutr. Dévelop., 1981, 21 (2), 193-197.

\title{
Plant protein biosynthesis : methionyl-tRNA synthetases, a new example of the cooperative activity of nucleo-cytoplasmic and organellar systems
}

\author{
par R. JULIEN, Michèle MOURICOUT, Bernadette QUINTARD, J. R. CARIAS
}

Laboratoire de Biochimie, UER des Sciences

123, rue Albert-Thomas, 87060 Limoges cedex, France.

Summary. The cooperative activity of nucleoplasmic and organellar systems appears to be of paramount importance for plant protein biosynthesis. Methionyl-tRNA synthetases from wheat were encoded in nuclear DNA, synthesized in cytoplasm and segregated into different compartments following post-translational events.

\section{Introduction.}

Plant protein biosynthesis is located in both the cytoplasm and the organelles, especially in chloroplasts whose proteins account for approximately 50 p. 100 of the cell protein content (Ellis, Blair and Hartley, 1973).

Based on a genome size of about $1.10^{8}$, the theoretical number of proteins which can be synthesized in the chloroplast is 120 units; each protein has a mean molecular weight of $5.10^{4}$ (Cifferi, 1978). This is not enough for an autonomous living status, and thus many chloroplast proteins in the soluble fraction as well as the membranebound ones are coded in the nuclear genome, translated in the cell cytoplasm and imported into the organelle.

Moreover, at least one soluble chloroplast protein (ribulose diphosphate carboxylase) and one membrane-bound (coupling factor CF1) are composed of polypeptides synthesized in different cell compartments (nucleus and chloroplast) (Mendola-Morgenthaler, Morgenthaler and Price, 1976). Thus, the cooperative activity of the nucleocytoplasmic and organellar systems appears to be of paramount importance for chloroplast development and function.

The most detailed reports of the interaction between the nuclear genetic system and that in the chloroplast concern the synthesis of ribulose diphosphate carboxylase. This enzyme, representing up to 50 p. 100 of the soluble chloroplast protein, is composed of large (MW : 54000$)$ and small (MW : 14000) sub-units with probably 8 of each of these sub-units per enzyme molecule ((Kawashima and Wildman, 1970). The large sub-unit is coded in the chloroplast DNA (Chan and Wildman, 1972) and synthesized in the organelle (Blair and Ellis, 1973), while the small sub-unit is coded (Kawashima 
and Wildman, 1972) and synthesized in the nucleocytoplasm (Dobberstein, Blobel and Chua, 1977 ; Highfield and Ellis, 1978).

The small sub-unit precursor (MW : 20000) from isolated pea and spinach chloroplasts is synthesized to completion in the cytoplasm and then transported into the chloroplast. It has an additional sequence at its $\mathrm{N}$-terminal but this is removed by a processing enzyme, which is not membrane-associated but soluble, located in the stroma fraction of the chloroplast (Ellis, 1979). It appears that this model can be demonstrated for many polypeptides synthesized in cell-free systems programmed with cytoplasmic mRNA, and there are signs that a similar mechanism operates for mitochondria and peroxysomes (Chua and Schmidt, 1979).

Preliminary results on plant aminoacyl-tRNA synthetases indicate that both the chloroplastic and the cytoplasmic enzymes are encoded in nuclear DNA, synthesized in cytoplasm and segregated into different compartments after a post-translational event (Parthier, Krauspe and Müller-Uri, 1976).

\section{Materials and methods.}

Quiescent wheat embryos and etiolated or green wheat seedlings were obtained from commercial caryops.

Crude and purified methionyl-tRNA synthetases and tRNAs Met from wheat were prepared according to Chazal ef al. $(1975,1977)$ and Quintard ef al. (1978). The chloroplastic enzymes, extracted from purified chloroplasts, were all analyzed by PAG electrophoresis and electrofocalization ( $\mathrm{pH}$ range : $3.5-9$ ) to determine their molecular weight, quaternary structure and $\mathrm{pHi}$. Assays for ability to methionylate tRNAMet enzymatically were performed according to Rosa and Sigler (1977) and Quintard ef al. (1978).

\section{Results and discussion.}

Plant cells contain several iso-tRNAs Met which can be separated into two main species : (i) prokaryotic tRNAsMet composed of mitochondrial and chloroplastic $t R N A_{f}^{\text {Met }}$ and tRNA $A_{m}^{\text {Met }}$ and (ii) eukaryotic tRNAs ${ }^{\text {Met }}$, including cyloplasmic IRNA $A_{i}^{\text {Met }}$ and tRNA $\mathrm{m}_{m}^{\text {Met }}$ (Ghosh et al., 1975). These molecules are methionylated in vivo by several enzymatic species (Weil et al., 1977). The data summarized in table 1 show that : - high-molecular cytoplasmic pre-enzymatic complexes from wheat can aminoacylate all the cytoplasmic $+R N A s$ Met ;

- cytoplasmic free enzyme (MW: $165000, \beta_{2}$ ) can also aminoacylate all cytoplasmic tRNAs ${ }^{\mathrm{Met}}$, except the organellar ones ;

- cytoplasmic proteolysed enzyme (MW : $70000, \alpha)$, a product of the two precedent species (fig. 1), only aminoacylates cytoplasmic tRNA $\mathrm{M}_{\mathbf{i}}^{\mathrm{Met}}$;

- a chloroplastic enzyme (MW: $70000, \alpha$ ), imported from the cytoplasm and segregated into the prokaryotic compartment, can aminoacylate prokaryotic $T$ RNAs Met, including chloroplastic tRNA ${ }^{\text {Met }}$ and cyfoplasmic tRNA ${ }_{i}^{\text {Met }}$ (fig. 2). 
TABLE 1

Physical and functional properties of some bacierial and plant methionyl-tRNA synthetases

\begin{tabular}{|c|c|c|c|c|c|}
\hline $\begin{array}{l}\text { Bacteria } \\
\text { or plant }\end{array}$ & $\begin{array}{l}\text { Subcellular } \\
\text { localisation }\end{array}$ & M.W. & Q.S. & $\begin{array}{l}\text { tRNAMet } \\
\text { substrate }\end{array}$ & $\begin{array}{l}\text { Bibliographical } \\
\text { reference }\end{array}$ \\
\hline E. coli & Cytoplasmic & 170000 & $\beta_{2}$ & Pro.tRNAsMet & $\begin{array}{l}\text { Cassio and Waller, } \\
1971\end{array}$ \\
\hline E. coli & $\begin{array}{l}\text { Cytoplasmic } \\
\text { (trypsinized } \\
\text { enzyme) }\end{array}$ & 60000 & $\alpha$ & Pro.tRNAsMet & $\begin{array}{l}\text { Cassio and Waller, } \\
1971\end{array}$ \\
\hline Lupine & Cytoplasmic & 165000 & $\beta_{2}$ & tRNAs ${ }^{\mathrm{Met}}$ & $\begin{array}{l}\text { Joachimiak et al., } \\
1978\end{array}$ \\
\hline $\begin{array}{l}\text { Quiescent wheat } \\
\text { embryo }\end{array}$ & Microsomal & $>3.10^{6}$ & $\beta_{2}$ & tRNAs ${ }^{\text {Met }}\left({ }^{1}\right)$ & Quintard ef al., 1978 \\
\hline \multirow{2}{*}{$\begin{array}{l}\text { Quiescent wheat } \\
\text { embryo }\end{array}$} & Cytosol & 165000 & $\beta_{2}$ & tRNAs ${ }^{\text {Met }}\left({ }^{1}\right)$ & Chazal, 1975 \\
\hline & & $\begin{array}{c}70000 \\
\text { (proteolyzed } \\
\text { enzyme) }\end{array}$ & $\alpha$ & Cyto.tRNAMet & $\begin{array}{l}\text { Thomes and Julien, } \\
\text { unpublished data } \\
\text { (fig 1) }\end{array}$ \\
\hline \multirow[t]{2}{*}{ Wheat embryo } & Cytoplasmic & 105000 & $\beta$ & IRNAs ${ }^{\text {Met }}\left({ }^{(1)}\right)$ & $\begin{array}{l}\text { Rosa and Siegler, } \\
1977\end{array}$ \\
\hline & & 70000 & $\alpha$ & $\begin{array}{l}\text { tRNA } A_{f}^{\text {Met }} \text { and } \\
\operatorname{tRNA}_{i}^{M e t}\end{array}$ & $\begin{array}{l}\text { Rosa and Siegler, } \\
1977\end{array}$ \\
\hline \multirow{2}{*}{$\begin{array}{l}\text { Etiolated and } \\
\text { green wheat } \\
\text { seedlings }\end{array}$} & Cyłoplasmic & 165000 & $\beta_{2}$ & tRNAsMet & $\begin{array}{l}\text { Quintard and Julien } \\
\text { unpublished data: }\end{array}$ \\
\hline & & 70000 & $\alpha$ & $\begin{array}{l}\text { Cyto.tRNA } A_{i}^{\text {Met }} \\
\text { Pro:tRNAMet }\end{array}$ & $\begin{array}{l}\text { Quintard and Julien, } \\
\text { unpublished data }\end{array}$ \\
\hline $\begin{array}{l}\text { Green wheat } \\
\text { seedlings }\end{array}$ & Chloroplastic & 70000 & $\alpha$ & $\begin{array}{l}\text { Pro.tRNAMet } \\
\text { Cyto.tRNA }\end{array}$ & $\begin{array}{l}\text { Carias and Julien, } \\
\text { unpublished data } \\
\text { (fig. 2) }\end{array}$ \\
\hline
\end{tabular}

(1) Except organellar TRNAMet ; Pro. : procaryotic ; Cyto. : cytoplasmic. M.W. : molecular weight ; Q.S. : quaternary structure.

From this data, it appears that the organellar enzyme encoded in the nucleus was produced in the cytoplasm by endogenous proteolysis of native cytoplasmic enzymes and then probably imported into the prokaryotic compartment. It is interesting that the only apparent functional property which was conserved during the transformation process was the ability to aminoacylate the cytoplasmic tRNAMet initiator. This molecule has two unique features: (i) unlike other eukaryotic initiator tRNAMet species, wheat germ $\operatorname{tRNA} A_{i}^{\text {Met }}$ is not recognized by $E$. coli transformylase, although it is charged with $E$. coli synthetase, and (ii) it cannot insert methionine in the internal position of the peptide chain, whereas other initiator IRNAMet species can donate methionine in internal positions (Ghosh et al., 1974).

It can be concluded that, although cytoplasmic tRNA $\mathrm{A}_{i}^{\text {Met }}$ was methionylated by the chloroplastic enzyme, it could not initiate protein synthesis in the organellar system since it was not be recognized by the transformylase.

Cytoplasmic wheat germ tRNA $A_{i}^{\text {Met }}$ should play a regulatory role, but this would only be possible if there is import across the membrane. 

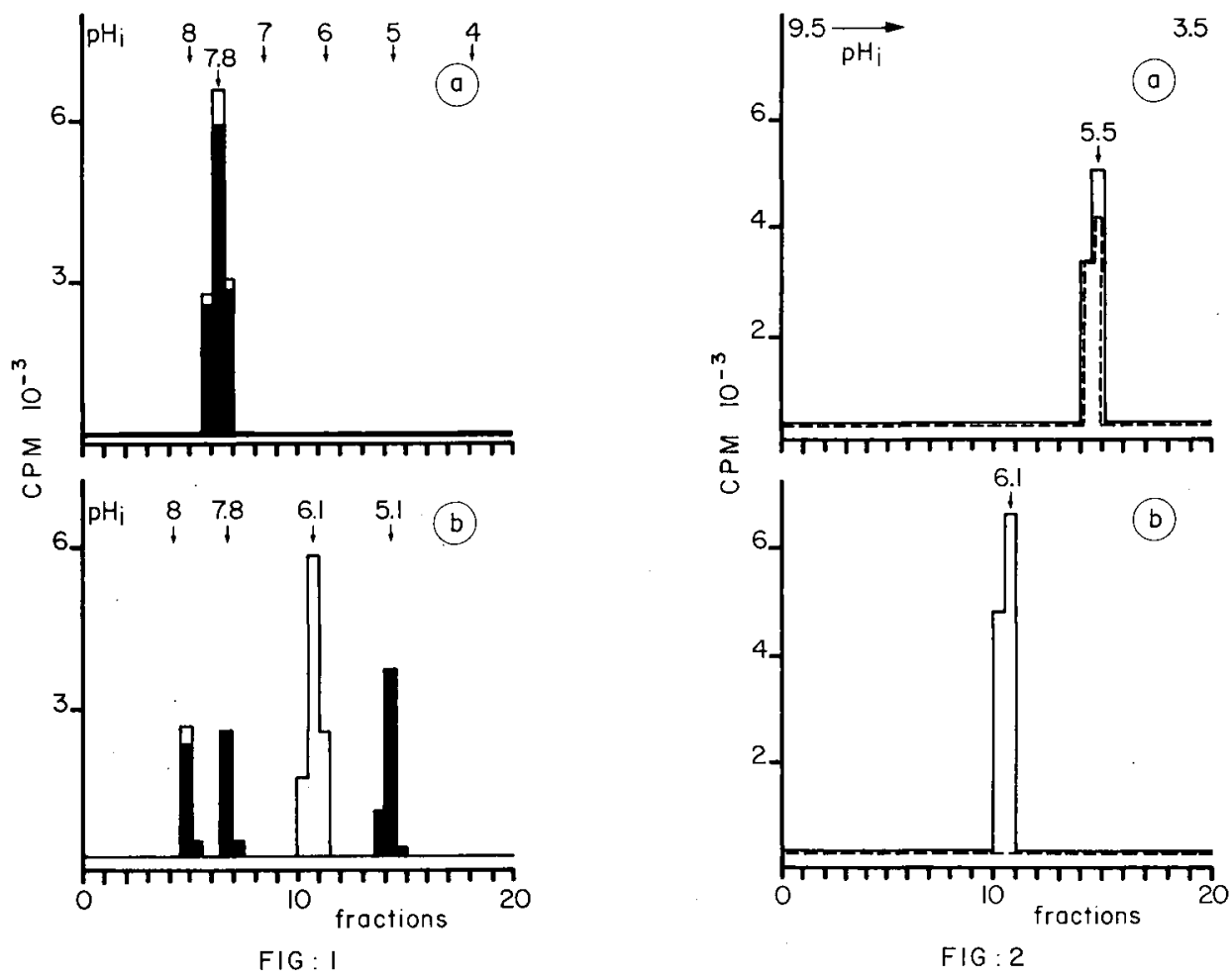

FIG. 1. - PAG electrofocalisation of high-molecular weight pre-enzymatic complexes and membrane-bound cyfoplasmic Met-tRNA synthetose.

Assays were performed with : - prokaryotic-tRNA; a cytoplasmic-tRNA ${ }_{1}^{\text {Met }}$ (see Materials and methods).

a) before incubation; b) after incubation $\left(37^{\circ} \mathrm{C}, 1 \mathrm{~h}\right)$.

FIG. 2. - PAG electrofocalisation of chloroplastic enzyme and cytoplosmic proteolysed enzyme.

Assays were performed with : - . - . - chloro-tRNA ; a cyto-tRNA $A_{i}^{\text {Met }}$ (see Materials and methods).

a) chloroplastic enzyme ; b) cytoplasmic proteolysed enzyme.

The possible post-translational events characterizing the transformation of the cytoplasmic enzyme into organellar enzymes are : dissociation of the non-covalent $\beta_{2}$ structure, specific proteolysis and the chemical modifications necessary for import across the membrane, and ability to aminoacylate organellar TRNAMet.

As proteins, plant methionyl-tRNA synthetases are no more interesting than numerous other discrete proteins synthesized in the cytoplasm before importation into the organelle. However, as enzymes, capable of producing iso-Met-tRNAsMet, especially those used for cytoplasmic and organellar protein biosynthesis initiation, their functional properties are of paramount importance. 
Résumé. La biosynthèse des protéines dans une cellule végétale fait appel à une coopération développée des systèmes localisés dans différents compartiments. Dans le cas des méthionyl-tRNA synthétases, ces enzymes codées par des gènes nucléaires sont fabriquées dans le cytoplasme et importées finalement, à la suite de modifications, dans les différents compartiments cellulaires.

\section{References}

BLAIR G. E., ELLIS R. J., 1973. Protein synthesis in chloroplasts. I. Light driven synthesis of the large subunit of fraction 1 protein by isolated pea chloroplasts. Biochim. biophys. Acta, 319, 223-234.

CASSIO D., WALLER J. P., 1971. Modification of methionyl-tRNA synthetase by proteolytic cleavage and properties of the trypsin-modified enzyme. Eur. J. Biochem., 20, 283-300.

CHAN P. H., WILDMAN S. G., 1972. Chloroplast DNA codes for the primary structure of the large subunit of fraction I protein. Biochim. biophys. octa, 277, 677-680.

CHAZAL Ph., THOMES J. C., JULIEN R., 1975. Methionine : tRNA ligase from wheat germ. Purification and properties. FEBS Letfers, 56, 268-272.

CHAZAL Ph., THOMES J. C., JULIEN R., 1977. Méthionyl-łRNA synthetase des embryons de blé : dissociation en sous-unités. Eur. J. Biochem., 73, 607-615.

CIFFERI O., 1978. The chloroplast DNA mystery. Trends biochem. Sci., 3, 256-258.

CHUA N. H., SCHMIDT G. W., 1979. Transport of proteins into mitochondria and chloroplasts. J. Cell Biol., 81, 461-483.

DOBBERSTEIN B., BLOBEL G., CHUA N., 1977. In vifro synthesis and processing of a putative precursor for the small subunit of ribulose-1,5-bisphosphate carboxylase of Chlamydomonas reinhardtii. Proc. not. Acad. Sci. U. S., 74, 1082-1085.

ELLIS R. J., 1979. The most abundant protein in the world. Trends biochem. Sci., 4, 241-244.

ELLIS R. J., BLAIR G. E., HARTLEY M. R., 1973. Protein synthesis in chloroplasts. Biochem. Soc. Symp., 38, 137-162.

GHOSH K., GHOSH J. P., SIMSEK M., RAJBHANDARY U. L. J., 1974. Initiator methionine transfer ribonucleic acid from wheat embryo. Purification, properties and partial nucleotide sequences. J. biol. Chem., 249, 4720-4729.

HIGHFIELD P. E., ELLIS R. J., 1978. Synthesis and transport of the small subunit of chloroplast ribulose biphosphate carboxylase. Nafure (London), 271, 420-424.

JOACHIMIAK A., BARCISZEWSKI J., TWARDOWSKI T., BARCISZEWSKA M., WIEWIOROWSKI M., 1978. Purification and properties of methionyl-tRNA synthetase from Yellow Lupine seeds. FEBS Letfers, 83, 51-54.

KAWASHIMA N., WILDMAN S. G., 1970. Fraction I protein. Ann. Rev. Plant Physiol., 21, $325-358$.

KAWASHIMA N., WILDMAN S. G., 1972. Studies on fraction I protein. IV. Mode of inheritance of primary structure in relation to whether chloroplast or nuclear DNA contain the code for a chloroplast protein. Biochem. biophys. Acta, 262, 42-49.

MENDIOLA-MORGENTHALER L. R., MORGENTHALER J. J., PRICE C. A., 1976. Synthesis of coupling factor $C F_{1}$ protein by isolated spinach chloroplasts. FEBS Lefters, 62, 96-100.

PARTHIER B., KRAUSPE R., MÜLLER-URI F., 1976. Specificity of chloroplast protein synthesis on the aminoacyl-tRNA level, 398-401. In LEGOCKI A. B., Translation of natural and synthetic polynucleotides, Poznan Agric. Univ.

QUINTARD B., MOURICOUT M., CARIAS J. R., JULIEN R., 1978. Occurrence of aminoacyl-tRNA synthetase complexes in quiescent wheat germ. Biochem. biophys. Res. Commun., 85, 999-1006.

ROSA D. M., SIGLER P., 1977. Isolation and characterization of two methionine : tRNA ligases from wheat germ. Eur. J. Biochem., 78, 141-151.

WEIL J. H., BURKARD G., GUILLEMAUT P., JEANNIN G., MARTIN R., STEINMETZ A., 1977. tRNAs and aminoacyl-tRNA synthetases in plant cytoplasm, chloroplasts and mitochondria, 97-120. In BOGORAD L., WEIL J. H., Nucleic acids and protein synthesis in plants. Plenum Publishing Corporation. 